\title{
A comparison study of insulin concentrations in follicular fluid, serum and in vitro-production of bovine embryos - risks of generating unfavourable metabolic conditions during early development
}

\author{
Denise Laskowski ${ }^{1 *}$, Ylva Sjunnesson ${ }^{1}$, Hans Gustafsson ${ }^{1}$, Patrice Humblot ${ }^{1}$, Göran Andersson², Renée Båge ${ }^{1}$
}

From Animal Obesity - causes, consequences and comparative aspects

Uppsala, Sweden. 14-16 June 2015

\section{Introduction}

Insulin has frequently been used as a stimulatory factor in routine in vitro embryo production (IVP) and is added in supra-physiological concentrations to different media. Meanwhile, insulin as a key metabolic hormone is elevated in patients with metabolic syndrome or diabetes, syndromes known to impair fertility.

\section{Objective}

This study compared in vitro-used and in vivo-measured insulin concentrations and elucidates explanations and risks for this difference.

\section{Methods and results}

Eleven in vivo-studies measuring insulin in serum or follicular fluid have been compared to nine IVP-protocols using insulin. In vitro concentrations were much higher than in vivo while not much is known about the different activity and stability of insulin in vitro versus in vivo. We measured insulin concentrations before and after maturation in an experimental trial using a quantitative ELISA (Mercodia bovine insulin ELISA Immunoassay) and can report stable quantities after 22 hours of incubation.

\section{Conclusion}

The uncritical use of supra-physiological insulin levels in vitro might have negative consequences for the developing embryo as insulin has direct effects on metabolism and could even influence the epigenetic programming of

\footnotetext{
* Correspondence: denise.laskowski@slu.se

'Department of Clinical Sciences, Swedish University of Agricultural Sciences, Uppsala, Sweden

Full list of author information is available at the end of the article
}

the metabolism with unknown consequences for the offspring later in life. Still, insulin may react differently in in vitro models where one explanation is different stability or activity of insulin. More precise dose effect studies have to be done to draw conclusions about consequences of the use of as high doses.

\section{Authors' details}

'Department of Clinical Sciences, Swedish University of Agricultural Sciences, Uppsala, Sweden. ${ }^{2}$ Department of Animal Breeding and Genetics, Swedish University of Agricultural Sciences, Uppsala, Sweden.

Published: 25 September 2015

doi:10.1186/1751-0147-57-S1-P5

Cite this article as: Laskowski et al:: A comparison study of insulin concentrations in follicular fluid, serum and in vitro-production of bovine embryos - risks of generating unfavourable metabolic conditions during early development. Acta Veterinaria Scandinavica 2015 57(Suppl 1):P5.

Submit your next manuscript to BioMed Central and take full advantage of:

- Convenient online submission

- Thorough peer review

- No space constraints or color figure charges

- Immediate publication on acceptance

- Inclusion in PubMed, CAS, Scopus and Google Scholar

- Research which is freely available for redistribution

Submit your manuscript at www.biomedcentral.com/submit
() Biomed Central 